\title{
HUBUNGAN ANTARA MOTIVASI BELAJAR DENGAN DISIPLIN BELAJAR SISWA
}

\author{
Surya Nugraheni \\ Universitas Kristen Satya Wacana, Jawa Tengah-Indonesia \\ email : 132015023@student.uksw.edu
}

\begin{abstract}
ABSTRAK
Penelitian ini bertujuan untuk mengetahui adakah Hubungan Antara Motivasi Belajar dengan Disiplin Belajar Siswa Kelas XI MIPA SMA Negeri 1 Bringin Tahun Ajaran 2018/2019. Jenis penelitian ini adalah penelitian kuantitatif. Teknik analisis data yang digunakan adalah Kendall's Tau. Teknik pengambilan sampel menggunakan teknik total sampling. Pengambilan sampel menggunakan sampel total seluruh siswa kelas XI MIPA SMA Negeri 1 Bringin yang berjumlah 136 siswa. Pengumpulan data menggunakan dua jenis skala, yaitu skala, motivasi belajar dan disiplin belajar yang dikembangkan oleh peneliti berdasarkan teori dari Sudjana (2005) dan dikembangkan oleh Dimyati dan Mudjiono (2013), dan teori dari Hurlock (1989). Pengolahan datanya menggunakan progam SPSS for Windows 17.0 version. Hasil penelitian menunjukkan bahwa ada hubungan motivasi belajar dengan disiplin belajar siswa kelas XI MIPA SMA Negeri 1 Bringin tahun pelajaran 2018/2019, dengan nilai $r=0,459$ dan koefesien signifikansi 0,000 $\leq 0,05$. Maka hubungan kedua variabel tersebut positif dan signifikan. Dengan demikian, hipotesis peneliti "Ada Hubungan Signifikan Antara Motivasi Belajar dengan Disiplin Belajar Siswa Kelas XI MIPA SMA Negeri 1 Bringin Tahun Ajaran 2018/2019".
\end{abstract}

Kata Kunci : Motivasi Belajar, Disiplin Belajar

\begin{abstract}
This study aims to determine whether there is a Relationship Between Motivation to Learn and Learning Discipline of Class XI MIPA Students of SMA 1 Bringin Academic Year 2018/2019. This type of research is quantitative research. The data analysis technique used is Kendall's Tau. The sampling technique uses total sampling technique. Sampling uses a total sample of all students of class XI MIPA 1 State High School Bringin, amounting to 136 students. Data collection uses two types of scales, namely scale, learning motivation and learning discipline developed by researchers based on the theory of Sudjana (2005) and developed by Dimyati and Mudjiono (2013), and theories from Hurlock (1989). Processing the data using the SPSS program for Windows 17.0 version. The results showed that there was a correlation between learning motivation and learning discipline in class XI MIPA students of SMA 1 Bringin in academic year 2018/2019, with a value of $r=0.459$ and significance coefficient of 0,000 a 0.05 . Then the relationship between the two variables is positive and significant. Thus, the researcher's hypothesis "There is a Significant Relationship Between Motivation to Learn and Student Discipline in Class XI MIPA of SMA 1 Bringin Academic Year 2018/1991".
\end{abstract}

Keywords: Learning Motivation, Learning Discipline 


\section{Pendahuluan}

Pendidikan merupakan faktor terpenting dalam kehidupan. Pendidikan tidak akan lepas dari manusia, karena dalam setiap aktivitas akan membutuhkan pembelajaran dari pendidikan. Peraturan pemerintah no 47 tahun 2008 tentang pelaksanaan wajib belajar sembilan tahun.Pemerintah menciptakan kebijakan dalam pendidikan sebagai tempat pengembangan bangsa. Sekolah merupakan salah satu pendidikan formal untuk melaksanakan proses pembelajaran dalam pendidikan.

Pembelajaran dalam sekolah harus optimal, pembelajaran yang optimal dalam suatu pendidikan sekolah pastinya akan melahirkan generasi penerus bangsa yang berkualitas. Pembelajaran yang optimal pastinya dipengaruhi beberapa faktor. Salah satu faktor yang mempengaruhi dalam belajar adalah motivasi belajar.

Sedangkan Menurut Sardiman (2012) motivasi belajar adalah keseluruhan daya penggerak di dalam diri siswa yang menimbulkan kegiatan belajar, yang menjamin kelangsungan dari kegiatan belajar dan memberikan arah dalam kegiatan belajar, sehingga tujuan yang dikehendaki oleh subjek belajar itu dapat tercapai.

Berdasarkan wawancara terhadap guru BK di SMA N 1 Bringin didapatkan hasil bahwa siswa kelas XI MIPA mempunyai motivasi belajar yang kurang.Kebanyakan mereka lebih asik bermain, pacaran, dan bermain handphone, sehingga menyebabkan mereka kurang disiplin dalam belajar. Berdasarkan uraian di atas menggugah penulis tertarik meneliti tentang "Hubungan antara Motivasi Belajar dengan Disiplin Belajar Siswa Kelas XI MIPA SMA N 1 Bringin".

Hasil penelitian yang dilakukan oleh Prasti (2005) dengan judul "Hubungan Antara Motivasi Belajar dengan Disiplin Belajar Siswa pada Saat Layanan Pembelajaran di Kelas II SMU Negeri Limbangan Kabupaten Kendal Tahun 2004/2005", menemukan korelasi antara disiplin belajar dengan motivasi belajar siswa sebesar 0,714 dengan signifikansi 0,000, dimana harga $r(5 \%: 44)$ dengan pendekatan $r(5 \%: 100)=0,195$. Karena signifikansinya $<0,05$ atau $r$ hitung $(0,714)>0,195$ maka korelasi tersebut signifikan artinya ada hubungan yang signifikan antara disiplin belajar dengan motivasi belajarsiswa.

Hasil penelitian yang dilakukan oleh Djahara (2017) yang berjudul "Hubungan Antara Motivasi Belajar dengan Disiplin Belajar pada Siswa Kelas XISMKN 5 Palu", memperoleh $r$ hitung $=0,312$. Dalam menentukan apakah hipotesis nol $(\mathrm{H} 0)$ diterima atau ditolak, maka selanjutnya dikonsultasikan pada $r$ tabel dengan $\mathrm{N}=59$ pada taraf signifikan $95 \%$ diperoleh $r$ tabel $=0,254$ oleh karena $r$ hitung $>r$ tabel atau 0,312 $>0,254$ berarti hipotesis nol $(\mathrm{H} 0)$ yang mengatakan bahwa tidak ada hubungan positif antara motivasi belajar dengan disiplin belajar siswa kelas XI SMK Negri 5 Palu ditolak.

Berdasarkan uraian pada latar belakang dan hasil penelitian-penelitian sebelumnya, maka penulis tertarik melakukan penelitian dengan judul "Hubungan Antara Motivasi Belajar dengan Disiplin Belajar Siswa Kelas XI MIPA SMA N 1 Bringin tahun pelajaran 2018/2019". Penelitian ini dilaksanakan dengan tujuan untuk mengetahui signifikansi hubungan antara motivasi belajar dengan disiplin belajar siswa SMA N 1 Bringin tahun pelajaran 2018/2019.

\section{Metode}

Jenis penelitian ini adalah penelitian korelasional. Populasi dalam penelitian ini adalah siswa kelas XI MIPA SMA N 1 Bringin yang berjumlah 136 siswa. Dalam menentukan sampel atau subjek penelitian peneliti menggunakan teknik sampeltotal. Penggunaan teknik sampel total dilakukan dengan cara mengambil subjek berdasarkan jumlah keseluruhan populasi sehingga yang menjadi sampel atau subjek penelitian adalah 136 siswa kelas XI MIPA SMA N 1 Bringin. Teknik analisis data yang digunakan dalam penelitian ini dengan menggunakan analisis korelasi Kendall-tau $b$. 
Uji Validitas

Koefisien validitas item (Corrected Item-Total Corelation) ditentukan valid jika koefesien kerelasi sama atau di atas $\geq 0,20$. Berdasarkan hasil uji validitas item variabel motivasi belajar terdapat 30 item (keseluruhan) tergolong valid dengan rentang koefisien korelasi 0,448 0,838 . Sedangkan hasil uji validitas item variabel disiplin belajar terdapat 30 item (keseluruhan) tergolong valid dengan rentang korelasi 0,488-0,869.

Uji Reliabilitas

Reliabilitas menunjukan pada suatu pengertian bahwa suatu instumen cukup dapat dipercaya untuk digunakan sebagai alat pengumpul data karena instrumen tersebut sudah baik (Arikunto, 2006).

Pengujian reliabilitas dilakukan dengan cara menguji coba instrument dan dianalisis dengan metode Alpha-Croncbach. Adapun hasil uji reliabilitas adalah sebagai berikut.

Tabel 1. Hasil Reliabilitas Motivasi Belajar

\section{Reliability Statistics}

$\begin{array}{ll}\text { Cronbach's Alpha } & \mathrm{N} \text { of Items } \\ .964 & 30\end{array}$

Dari uji reliabilitas 30 item pernyataan dalam skala motivasi belajar maka diperoleh angka koefisien Alpha =0,964 dan berada pada kategori reliabilitas istimewa.

Tabel 2. Hasil Reliabilitas Disiplin Belajar

\begin{tabular}{lrr}
\hline Reliability Statistics & \\
\hline Cronbach's Alpha & \multicolumn{2}{c}{ N of Items } \\
\hline & .968 & 30 \\
\hline
\end{tabular}

Dari uji reliabilitas 30 item pernyataan dalam skala disiplin belajar maka diperoleh angka koefisien Alpha $=0,968$ dan berada pada kategori reliabilitas istimewa

\section{Hasil Dan Pembahasan}

Deskripsi Subjek Penelitian

Penelitian ini dilakukan di SMA N 1 Bringin yang berlokasi di jalan Wibisono, Gang II/No. 3, Bringin Semarang, Jawa Tengah 50772. Subjek pada penelitian ini adalah siswa kelas XI MIPA SMA N 1 Bringin yang berjumlah 136 siswa. Rincian data subjek dapat dilihat dari tabel berikut:

Tabel 3. Data Subjek Siswa Kelas XI MIPA SMAN 1 Bringin

\begin{tabular}{ccc}
\hline No. & Kelas & Jumlah Siswa \\
\hline 1. & XI MIPA 1 & 33 \\
2. & XI MIPA 2 & 35 \\
3. & XI MIPA 3 & 34 \\
4. & XI MIPA 4 & 34 \\
& Total & $\mathbf{1 3 6}$ \\
\hline
\end{tabular}


Hasil Analisis Deskriptif

Analisis deskriptif variabel motivasi belajar digunakan untuk mengetahui tingkat keterbukaan diri yang dimiliki oleh siswa apakah dalam kategori sangat tinggi, tinggi, cukup, dan rendah, maka dapat dihitung dengan rumus sebagai berikut:

$$
\text { Interval }=\frac{\text { Jumlah skor tertinggi }- \text { jumlah skor terendah }}{\text { Jumlah kategori }}
$$

\begin{tabular}{|c|c|c|c|}
\hline Kategori & Interval & Frekuensi & Presentase (\%) \\
\hline Sangat tinggi & $102-120$ & 0 & $0 \%$ \\
\hline Tinggi & $84-101$ & 75 & $55 \%$ \\
\hline Sedang & $66-83$ & 60 & $44,3 \%$ \\
\hline Rendah & $48-65$ & 1 & $0,7 \%$ \\
\hline Sangat rendah & $30-47$ & 0 & $0 \%$ \\
\hline \multicolumn{2}{|c|}{ Total } & 136 & $100 \%$ \\
\hline \multicolumn{2}{|c|}{$\begin{array}{l}\text { Min } \\
\text { Max }\end{array}$} & \multicolumn{2}{|c|}{57} \\
\hline \multirow{2}{*}{\multicolumn{2}{|c|}{$\begin{array}{c}\text { Max } \\
\text { Mean }\end{array}$}} & \multicolumn{2}{|c|}{100} \\
\hline & & \multicolumn{2}{|c|}{83.76} \\
\hline
\end{tabular}

Tabel 4. Distribusi Frekuensi Motivasi Belajar

Berdasarkan Tabel 4, Distribusi Frekuensi diatas dapat diketahui bahwa motivasi belajar siswa kelas XI MIPA SMA N 1 Bringin sebagian besar berada pada kategori tinggi dengan presentase $55 \%$.

Analisis deskriptif variabel disiplin belajar digunakan untuk mengetahui tingkat keterbukaan diri yang dimiliki oleh siswa apakah dalam kategori sangat tinggi, tinggi, cukup, dan rendah, maka dapat dihitung dengan rumus sebagai berikut:

$$
\text { Interval }=\frac{\text { Jumlah skor tertinggi }- \text { jumlah skor terendah }}{\text { Jumlah kategori }}
$$

\begin{tabular}{|c|c|c|c|}
\hline Kategori & Interval & Frekuensi & Presentase (\%) \\
\hline Sangat tinggi & $102-120$ & 15 & $11 \%$ \\
\hline Tinggi & $84-101$ & 89 & $65.5 \%$ \\
\hline Sedang & $66-83$ & 32 & $23.5 \%$ \\
\hline Rendah & $48-65$ & 0 & $0 \%$ \\
\hline Sangat rendah & $30-47$ & 0 & $0 \%$ \\
\hline \multicolumn{2}{|c|}{ Total } & 136 & $100 \%$ \\
\hline \multicolumn{2}{|c|}{ Min } & \multicolumn{2}{|r|}{67} \\
\hline \multicolumn{2}{|c|}{$\operatorname{Max}$} & \multicolumn{2}{|r|}{108} \\
\hline \multicolumn{2}{|c|}{ Mean } & \multicolumn{2}{|r|}{89.81} \\
\hline
\end{tabular}

Tabel 5. Distribusi Frekuensi Disiplin Belajar

Berdasarkan tabel 5, Distribusi Frekuensi diatas dapat diketahui bahwa disiplin belajar siswa kelas XI MIPA SMA N 1 Bringin sebagian besar berada pada kategori tinggi dengan presentase $65,5 \%$.

Tabel 6. Tabel Interpretasi Korelasi

\begin{tabular}{cc}
\hline Interval Korelasi & Tingkat Hubungan \\
& Sangat Rendah \\
Rendah & Rend
\end{tabular}




$$
\begin{aligned}
& 0,40-0,599 \\
& 0,60-0,799 \\
& 0,80-1,000
\end{aligned}
$$

\author{
Sedang \\ Kuat \\ Sangat Kuat
}

Sumber : (Sugiyono 2011)

Menurut Sugiyono (2011), interpretasi koefesien korelasi digunakan untuk mengetahui adanya hubungan yang tinggi atau rendah antara kedua variabel berdasarkan nilai $r$ (koefisien korelasi), hal ini untuk mengetahui apakah nilai $r$ yang diperoleh tersebut berarti atau tidak. Seperti dijabarkan pada Tabel 6.

\section{Uji Hipotesis}

Uji hipotesis bertujuan untuk mengetahui ada atau tidak ada hubungan (korelasi) antara motivasi belajar dengan disiplin belajar siswa kelas XI MIPA SMA N 1 Bringin. Pengujian korelasi menggunakan Kendall's tau yang diolah dengan bantuan program SPSS.17. Hasil uji korelasi dapat dilihat sebagai berikut :

Tabel 7. Correlations

\begin{tabular}{rlrr} 
& & Disiplin Belajar & Motivasi Belajar \\
\hline Kendall's tau_b Disiplin Belajar & Correlation Coefficient & 1.000 & $.459^{* *}$ \\
& Sig. (2-tailed) & .000 \\
& $\mathrm{~N}$ & 136 & 136 \\
Motivasi & Correlation Coefficient & $.459^{* *}$ & 1.000 \\
Belajar & Sig. (2-tailed) & .000 &. \\
& $\mathrm{~N}$ & 136 & 136 \\
$*{ }^{* *}$. Correlation is significant at the 0.01 level (2-tailed). & & \\
\hline
\end{tabular}

Berdasarkan hasil uji korelasi diatas maka diketahui nilai $r=0,459$ dengan koefesien signifikansi $0,000 \leq 0,05$, dengan demikian dapat ditarik kesimpulan bahwa ada hubungan signifikan antara Motivasi Belajar dengan Disiplin Belajar siswa kelas XI MIPA SMA N 1 Bringin. Dari hasil koefisien korelasi pada pengujian hipotesis, diketahui koefisien korelasi 0,459 . Berdasarkan tabel 7 . menunjukkan tingkat hubungan yaitu antara $0,40-0,599$, yang artinya sedang.

Dari hasil uji hipotesis yang dilakukan, menunjukkan bahwa ada hubungan signifikan antara motivasi belajar dengan disiplin belajar siswa kelas XI MIPA SMA N 1 Bringin, dengan hasil koefisien korelasi antara dukungan sosial orang tua dengan kepercayaan diri dengan nilai $r=0,459$ dan koefesien signifikansi $0,000 \leq 0,05$, dengan demikian hipotesis diterima dan berbunyi ada hubungan yang signifikan antara motivasi belajar dengan disiplin belajar siswa kelas XI MIPA SMA N 1 Bringin.

Hasil penelitian ini mendukung dari hasil penelitian yang dilakukan oleh Prasti (2005) yang berjudul hubungan antara motivasi belajar dengan disiplin belajar, dalam penelitianya diperoleh korelasi antara motivasi belajar dengan disiplin belajar $(r)$ sebesar 0,714 dengan signifikansi 0,000 dimana harga $r(5 \%: 44)$ dengan pendekatan $r(5 \%: 100)=0,195$. Karena harga siginifikansinya $<0,05$ dan harga $r$ hitung $(0,714)>0,195$ maka harga korelasi tersebut signifikan artinya ada hubungan yang signifikan antara motivasi belajar dengan disiplin belajar.

Dapat dilihat juga berdasarkan deskripsi data tabel kategorisasi pada variabel motivasi belajar, dilihat dari tabel distribusi frekuensi, tingkat motivasi belajar siswa kelas XI MIPA SMA $\mathrm{N} 1$ Bringin, yang memilki kategori sangat rendah $0 \%$, kategoti rendah $0,7 \%$, kategori sedang 44,3\%, kategori tinggi 55\%, dan pada kategori sangat tinggi $0 \%$. Hal ini menunjukkan bahwa siswa kelas XI MIPA SMA N 1 Bringin tergolong memiliki motivasi belajar tinggi. Hal ini dapat diartikan bahwa siswa kelas X MIPA SMA N 1 Bringin memiliki motivasi belajar tinggi. 
Pada variabel disiplin belajar, dilihat dari tabel distribusi frekuensi, tingkat motivasi belajar siswa kelas XI MIPA SMA N 1 Bringin, yang memilki kategori sangat rendah 0\%, kategoti rendah $0 \%$, kategori sedang $23,5 \%$, kategori tinggi $65,5 \%$, dan pada kategori sangat tinggi $11 \%$. Hal ini menunjukkan bahwa siswa kelas XI MIPA SMA N 1 Bringin tergolong memiliki disiplin belajar tinggi. Hal ini dapat diartikan bahwa siswa kelas XI MIPA SMA N 1 Bringin memiliki disiplin belajar yang tinggi.

Menurut beberapa ahli berpendapat dikatakan bahwa disiplin belajar adalah sikap atau tingkah laku siswa yang taat dan patuh untuk dapat menjalankan kewajibannya untuk belajar, baik di sekolah maupun belajar di rumah. Menurut Agus (1987) disiplin belajar adalah predisposisi suatu sikap mental untuk mematuhi peraturan, tata tertib, dan sekaligus mengendalikan diri dan menunjukkan kesadaran akan tanggung jawab terhadap tugas dan kewajiban.

Menurut Sardiman (2012) motivasi belajar adalah keseluruhan daya penggerak di dalam diri siswa yang menimbulkan kegiatan belajar, yang menjamin kelangsungan dari kegiatan belajar dan memberikan arah dalam kegiatan belajar, sehingga tujuan yang dikehendaki oleh subjek belajar itu dapat tercapai. Motivasi belajar merupakan energy yang mendorong seseorang untuk melakukan aktivitas belajar dan memberikan arah pada kegiatan belajar tersebut sehingga tujuan belajar dapat tercapai.

\section{Simpulan dan Saran}

Berdasarkan hasil penelitian dapat disimpulkan bahwa ada hubungan antara motivasi belajar dengan disiplin belajar siswa kelas XI MIPA SMA N 1 Bringin tahun pelajaran 2018/2019, dengan nilai $r=0,459$ dan skor signifikansi $0,000 \leq 0,05$.

Adapun saran yang di sampaikan pada penelitian ini adalah

1. Bagi peneliti berikutnya,

a. Pada saat pengambilan data mengunakan kuisoner (angket) lebih baik peneliti memeriksa kembali kuisioner (angket) tersebut. Hal ini bertujuan untuk menanggulangi kuisoner (angket) yang tidak terisi penuh ataupun karena siswa tidak mengisi beberapa kuisioner (angket).

b. Untuk penelitian berikutnya diharapkan dapat menggunakan sampel yang lebih banyak sehingga hasil penelitian dapat di generalisasikan.

2. Bagi guru

Berdasarkan penelitian ini setelah guru mengetahui hubungan moytivasi belajar dengan disiplin belajar diharapkan guru dapat berperan dalam membantu siswa untuk menyadari perlunya berdisiplin dalam belajar. Selain memotivasi siswa untuk disiplin belajar, guru juga dihimbau untuk melakukan pembelajaran yang kreatif dan menarik dehingga siswa juga dapat termotivasi dalam belajar. Kedisplinan di kelas juga penting dalam menciptajan ruang kelas yang kondusif serta nyaman untuk belajar.

\section{Daftar Rujukan}

Arikunto, Suharsini. 1990. Manajemen Pengajaran secara Manusiawi.Jakarta: PT Rineka Cipta.

Arikunto, Suharsini. 2002. Prosedur Penelitian (Suatu Pendekatan Praktek).Jakarta: PT Rineka Cipta.

Arikunto, Suharsini. 2006. Prosedur Penelitian Suatu Pendekatan Praktek. Jakarta: PT Rineka Cipta. 
George, D. Mallery. 1995. SPSS for windows 1995 step by step: A Simple Guide and Reference 16.0 Update. Allyn and Bacon, Boston.

Djamrah, Syaifu Bahri. 2008. Psikologi Belajar. Jakarta: Rineka Cipta.

Dimyati \& Mudjiono.2013.Psikologi dan Pembelajaran.Jakarta: Rineka Cipta.

Hamalik, Oemar.2004. Psikologi Belajar dan Mengajar. Bandung: Sinar Baru Algensindo.

Prasti, Herlin FD. 2005. Hubungan antara Motivasi Belajar dengan Disiplin Belajar Siswa Pada Saat Layanan di Kelas II SMU Negri 1 Limbangan Kabupaten Kendal Tahun 2004/2005. UNES.

Sardiman.2014. Interaksi dan Motivasi Belajar-Mengajar. Jakarta:Rajawali Pers.

Slameto. 2003. Belajar dan Faktor-Faktor Yang Mempengaruhinya. Jakarta: PT Rineka Cipta.

Sudjana, N. 2005.Penilaian Hasil Proses Belajar Mengajar. Bandung: PT Remaja Kosdakarya.

Sugiyono. 2010. Metode Penelitian Kuantitatif Kualitatif dan R\&D. Bandung: Alfabeta.

Sugiyono. 2011. Metode Penelitian Kuantitatif, Kualitatif dan R\&D. Bandung : Alfabeta

Sugiyono. 2009. Metode Penelitian Administrasi. Bandung: CV Alfabeta.

Ibrahim.S.H. 2015.Hubungan Antara Motivasi Belajar dengan Perilaku membolos pada siswa Kelas VIII Smp Batik Surakarta.Surakarta.Skripsi. Fakultas Ekonomi. UMS

Tu'u, Tulus. 2004. Peran Disiplin pada Perilaku Peserta Siswa.Jakarta: Gramedia Pustaka Utama.

Winardi, J. 2001. Motivasi dan Pemotivasian dalam Managemen.Jakarta: Raja Grafindo Persada.. 